\title{
Publisher Correction: The long non-coding RNA HOXB-AS3 regulates ribosomal RNA transcription in NPM1-mutated acute myeloid leukemia
}

Dimitrios Papaioannou, Andreas Petri D, Oliver M. Dovey, Sara Terreri, Eric Wang, Frances A. Collins, Lauren A. Woodward, Allison E. Walker, Deedra Nicolet, Felice Pepe (1), Prasanthi Kumchala, Marius Bill, Christopher J. Walker, Malith Karunasiri, Krzysztof Mrózek, Miranda L. Gardner, Virginia Camilotto, Nina Zitzer, Jonathan L. Cooper, Xiongwei Cai, Xiaoqing Rong-Mullins (D), Jessica Kohlschmidt, Kellie J. Archer (D), Michael A. Freitas, Yi Zheng, Robert J. Lee, lannis Aifantis, George Vassiliou (D, Guramrit Singh (D), Sakari Kauppinen, Clara D. Bloomfield (D), Adrienne M. Dorrance \& Ramiro Garzon

Correction to: Nature Communications https:/doi.org/10.1038/s41467-019-13259-2, published online 25 November 2019.

The original version of this Article contained an error in the author affiliations.

Affiliation number 9 incorrectly read "Department of Molecular Medicine, University of Pavia, Pavia, USA"

This has now been corrected in both the PDF and HTML versions of the Article

Published online: 07 January 2020

\footnotetext{
(c) Open Access This article is licensed under a Creative Commons Attribution 4.0 International License, which permits use, sharing, adaptation, distribution and reproduction in any medium or format, as long as you give appropriate credit to the original author(s) and the source, provide a link to the Creative Commons license, and indicate if changes were made. The images or other third party material in this article are included in the article's Creative Commons license, unless indicated otherwise in a credit line to the material. If material is not included in the article's Creative Commons license and your intended use is not permitted by statutory regulation or exceeds the permitted use, you will need to obtain permission directly from the copyright holder. To view a copy of this license, visit http://creativecommons.org/licenses/by/4.0/.
}

(C) The Author(s) 2020 